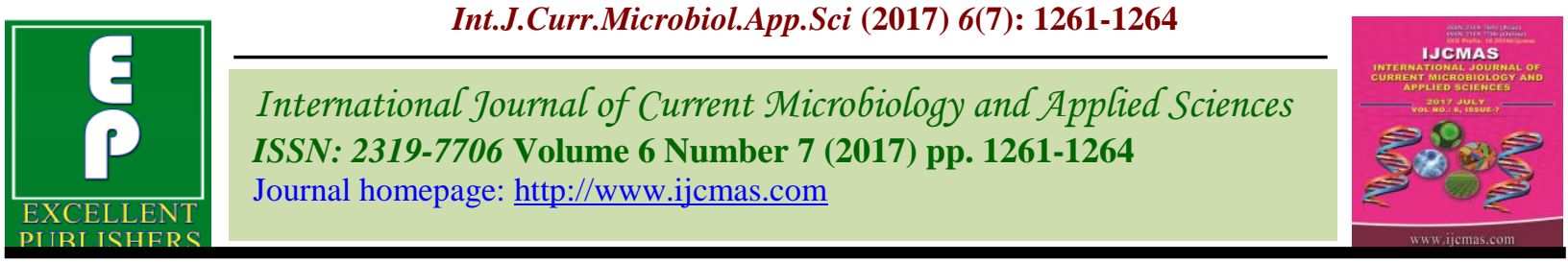

Original Research Article https://doi.org/10.20546/ijcmas.2017.607.153

\title{
Management of Sunflower Powdery Mildew Using Fungicide
}

\author{
P. Madhusudhan ${ }^{1}$, Y. Narasimhudu ${ }^{2}$, K. Ashok Kumar ${ }^{3}$, S. Neelima ${ }^{4}$ and A.S.R. Sarma ${ }^{5}$ \\ ${ }^{1}$ Agricultural Research Station, Acharya N.G. Ranga Agricultural University (ANGRAU), \\ Nellore -524 003, India \\ ${ }^{2}$ Krishi Vigyan Kendra, ANGRAU, Banavasi -518 360, India \\ ${ }^{3}$ College of Agricultural Engineering, ANGRAU, Madakasira-515 301, India \\ ${ }^{4}$ All India Coordinated Research Project on Sunflower, ${ }^{5}$ All India Coordinated Research Project \\ on Cotton, Regional Agricultural Research Station, ANGRAU, Nandyal-518502, India \\ *Corresponding author
}

\section{A B S T R A C T}

Powdery mildew caused by Golovinomyces cichoracearum (DC) V.P Heluta Var. cichoracearum is one of the important diseases of sunflower causing yield losses to a

Keywords

Fungicides, Powdery mildew and Sunflower. considerable extent. Seven fungicides: Wettable sulphur 80wp@0.2\%, triadimefon 25wp@0.1\%, triadimorph 80EC@0.05\%, difenconazole 25EC@0.05\%, propiconazole 25EC@0.1\%, carbendazim 50wp@0.1\% and benomyl 50wp@0.1\% were evaluated in Randomized Block design under field conditions. All the fungicides were sprayed twice with fifteen days interval against the disease. The experiment conducted for three consecutive years:2009-10 to 2011-12.Pooled analysis data revealed that among the fungicides tested propiconazole 25EC@0.1\% recorded least per cent disease index $(17.3 \%)$, highest yield $(1134 \mathrm{~kg} / \mathrm{ha})$ and net returns. It is at par with triadimefon $25 \mathrm{wp}$ $@ 0.1 \%$ with regards to per cent disease index $(21.3 \%)$, but not with yield $(1074 \mathrm{~kg} / \mathrm{ha})$. In control highest per cent disease index $(79.6 \%)$ and lowest yield $(763 \mathrm{~kg} / \mathrm{ha})$ were recorded. The per cent disease index ranged from 23.2 to $35.3 \%$ in rest of the treatments. From the experimental results obtained, Propiconazole 25EC@0.1\% has been recommended to the farming communities for management of the disease.

\section{Introduction}

Sunflower (Helianthus annuus L.) is an important oil seed crop of the family Asteraceae. It has advantage over other annual oilseed crops due to its wider adaptability to diverse agro-climatic conditions, short duration, high yield potential, ability to withstand drought, photoperiod insensitivity, lower seed rate, high seed multiplication ratio and high quality edible oil (Sindai and Virupakshappa, 1986). Sunflower is rich source of edible oil (40$48 \%$ ) having anticholesterol properties due to the presence of poly unsatured fatty acids (55-
$65 \%$ ) linoleic acid and 20-30\% oleic acid) (Joksimovie et al., 2006). Presently, in India it is occupied more than 5.20 lakh hectares area with a production of 3.35 lakh tonnes and productivity of $643 \mathrm{~kg} / \mathrm{ha}$ (Anonymous, 2017). Its cultivation mainly confined to southern parts of the country comprising the states of Andhra Pradesh, Telangana, Karnataka, Maharashtra and Tamil Nadu. These five states contribute about 90 per cent of total acreage and 78 per cent of total production. During the past two decades, the area has expanded under rabi and spring in 
Rice fallows of Northern India. Profitable cultivation of the crop is limited by the vulnerability of the released varieties and hybrid to a multitude of diseases and pests. The Crop is infected by over 80 pathogens (Gulya and Masirevic, 1991). In India since the last decade powdery mildew caused by Golovinomyces cichoracearum (DC) V.P Heluta Var. cichoracearum (1988) Formerly Erysiphe cichoracearum Dc.ex Meret, 1805) has become one of the major diseases of sunflower. In India, the disease was first reported in Bombay (Patel et al., 1949) later in Rajastan (Prasada et al., 1968), West Bengal (Goswami and Dasgupta, 1981) and Punjab (Bains et al., 1996) causing a significant yield reduction. The disease originates as minute discoloured speck from which powdery mass radiates in all the sides of the leaves. Large area on the aerial parts of the host is covered with white powdery mass containing mycelia and conidia of the fungus (Singh, 1984). This disease causes considerable yield loss in Andhra Pradesh particularly in Rabi season. The present investigation was taken up to find out effective fungicides for efficient management of the disease.

\section{Materials and Methods}

A field experiment was conducted for three consecutive years from 2009-10 to 2011-12 during Rabi under All India Coordinated Research Project on sunflower (AICRP on sunflower) at Regional Agricultural Research Station (RARS), Nandyal. The experiment was laid out in Randomized block design with seven fungicide treatments: wettable sulphur 80wp@0.2\%, triadimefon 25wp@0.1\%, tridemorph 80EC@0.05\%, difenconazole 25EC@0.05\%, propiconazole 25EC@0.1\%, carbendazim 50wp@0.1\% and benomyl 50wp $@ 0.1 \%$ and untreated control replicated thrice.. Local popular Hybrid NDSH-1 was planted in experiment, plot size was $4.2 \times 3 \mathrm{~m}$ with spacing of $60 \times 30 \mathrm{~cm}$. Fungicide solutions were prepared by dissolving known quantity of fungicide in water to get desired concentration. The first spray was given on the appearance of the disease and second spray with 15 days interval. In each treatment, ten plants were tagged, the powdery mildew severity was recorded one day before the first spray and 15 days after the spray using 0-9 scale (Anonymous, 2011). Per cent Disease Index (PDI) was calculated by using the formula given by Wheeler (1969). At the time of harvest, sunflower heads from all treatments were weighed as per the replications separately and average weight was calculated. After threshing and winnowing, seed weight of each replication in kilogram was recorded and yield per hectare was computed by using net plot yield data and it was then converted to kilogram per hectare. The statistical analysis of Randomized Block Design was carried out as per the procedure given by Panse and Sukhatme (1985).

\section{Results and Discussion}

During the first year (2009-10) propiconazole 25EC@0.1\%, recorded least PDI (9.0\%) and highest yield $(817.9 \mathrm{~kg} / \mathrm{ha})$ is at par with difenconazole 25EC@0.05\%. Second year (2010-11) propiconazole 25EC @0.1\%, recorded least PDI (34.37 \%) and highest yield $(1066 \mathrm{~kg} / \mathrm{ha})$ is at par with tridemorph 80EC@ 0.05\%, and triadimefon 25wp @0.1\%. Third year (2011-12) propiconazole 25EC@0.1\% recorded least PDI (8.6\%) and Highest yield $(159 \mathrm{~kg} / \mathrm{ha})$ and is at par with triademefon 25wp@0.1\% and difenconazole 25EC@0.05\% (Table 1). Pooled analysis of three years data revealed that among the fungicides tested propiconazole 25EC@0.1\% recorded least per cent disease index(PDI) of $17.3 \%$, highest yield $(1134 \mathrm{~kg} / \mathrm{ha})$ and net returns. It is at par with triademefon $25 \mathrm{wp}$ @ $0.1 \%$ with regards to PDI $(21.3 \%)$, but not with yield (1074 kg/ha). 
Table.1 Per cent disease index of powdery mildew and seed yield in sunflower for three consecutive years (2009-10 to 2011 -12)

\begin{tabular}{|c|c|c|c|c|c|c|c|c|c|}
\hline \multirow{2}{*}{ Treatments } & \multicolumn{4}{|c|}{ Per cent disease index (PDI) } & \multicolumn{4}{|c|}{ Seed Yield (Kg/ha) } & \multirow{2}{*}{$\begin{array}{c}\text { Net returns } \\
\text { Rs/ha }\end{array}$} \\
\hline & 2009-10 & 2010-11 & 2011-12 & Pooled & 2009-10 & 2010-11 & 2011-12 & Pooled & \\
\hline $\mathbf{T}_{\mathbf{1}}: \quad$ Wettable sulphur 80wp @0.2\% & $24.0(29.35)$ & $51.95(46.32)$ & 29.6(32.9) & $35.2(36.4)$ & 680 & 839 & 1158 & 892 & 16826 \\
\hline $\mathbf{T}_{\mathbf{2}}: \quad$ Triadimefon $25 \mathrm{wp} @ 0.1 \%$ & $12.8(20.97)$ & $36.32(36.88)$ & $14.8(21.2)$ & $21.3(27.4)$ & 780 & 994 & 1447 & 1074 & 21902 \\
\hline $\mathbf{T}_{\mathbf{3}} \mathbf{:}$ Tridemorph80EC@ $0.05 \%$ & $15.6(23.28)$ & 35.89 (36.76) & $24.6(29.4)$ & $25.4(30.2)$ & 750 & 1005 & 1210 & 989 & 19432 \\
\hline $\mathbf{T}_{4}:$ Difenconazole 25EC @0.05\%, & $11.3(19.65)$ & $41.40(40.06)$ & $17.0(23.9)$ & $23.2(28.8)$ & 800 & 974 & 1417 & 1064 & 20622 \\
\hline $\mathbf{T}_{\mathbf{5}}: \quad$ Propiconazole 25EC @0.1\% & $9.0(17.47)$ & $34.37(35.74)$ & $8.6(17.0)$ & $17.3(24.6)$ & 818 & 1066 & 1519 & 1134 & 22962 \\
\hline T: $\quad$ Carbendazim 50wp @0.1\% & $19.2(26.00)$ & $44.35(41.77)$ & $23.5(29.0)$ & $29.0(32.6)$ & 700 & 940 & 1396 & 1012 & 20006 \\
\hline $\mathbf{T}_{7}: \quad$ Benomyl 50wp @0.1\% & $17.6(24.22)$ & $53.03(46.76)$ & $35.4(36.4)$ & $35.3(36.5)$ & 733 & 832 & 1154 & 907 & 16606 \\
\hline $\mathbf{T}_{\mathbf{8}}: \quad$ Control & $74.6(59.77)$ & $70.39(57.27)$ & $93.0(75.2)$ & $79.6(63.2)$ & 514 & 778 & 996 & 763 & 14114 \\
\hline CD at $5 \%$ & 4.66 & 2.06 & 10.6 & 4.1 & 33.96 & 118 & 116.1 & 53 & \\
\hline SEm \pm & 1.53 & 0.68 & 3.5 & 1.36 & 11.19 & 39 & 38.3 & 17 & \\
\hline
\end{tabular}

Figures in parenthesis are angular transformed values 
In control highest PDI (79.6\%) and lowest yield $(763 \mathrm{~kg} / \mathrm{ha})$ were recorded. Rest of the fungicidal treatments recorded 23.2 to $35.3 \%$ PDI (Table 1). From the experimental results obtained propiconazole 25EC @0.1\% has been recommended to farming communities for the management of the disease. Propiconazole belongs to triazoles group fungicides. These fungicides interfere with the biosynthesis of fungal sterols and inhibit ergosterol biosynthesis. Ergosterol is vital to the structure of cell wall and its deficiency causes irreversible damage to the cell wall and fungus dies. They will also interfere in conidia and haustoria formation (Nene and Thapliyal, 1993). Several workers reported that, propiconazole was found to be effective in reducing powdery mildew severity in various crops. Propiconazole and thiophanate methyl are effective in controlling the Dog wood powdery mildew (Mumbaga et al., 2004). Linseed powdery mildew caused by Oidium lini was successfully managed by Propiconazole $(0.1 \%)$, (Gohokar et al., 2016). Pea powdery mildew caused by Erysiphae polygoni also efficiently managed by Propiconazole.

\section{References}

Anonymous, 2011.Technical Programme, Annual group meeting on Sunflower. Directorate of Oilseeds Research, Hyderabad, p. 55.

Anonymous, 2017. Directors report, Annual group meeting on Sunflower, Indian Institute of Oilseeds Research, Rajendra Nagar, Hyderabad, p. 17

Bains, S.S., Sing, H., Singh, K. and Dhiman, J.S. 1996. Powdery mildew of sunflower in Punjab. Indian J. Mycol. Pl. Pathol., 26(1): 90-92.

Basandarai, D., Basandarai, A.K., Mittal, P. and Sharma, B.K. 2013. Fungicidal management of rust, powdery mildew and Ascochayta blight in seed crop of pea. Plant Dis. Res., 28(1): 22-28.

Gohokar, R.T., Biradar, V.K. and Banginwar, A.D. 2016. Efficacy of fungicides against linseed powdery mildew. Int. J. of Life Sci.,
A6: 37-39.

Goswami, B.K. and Dasgupta, M.A. 1981. Leaf blight, powdery mildew and charcoal rot diseases of sunflower from west Bengal. Indian Phytopath, 34(1): 14-16.

Gulya, J.J. and Masirevic, S. 1991. Common names for plant diseases of sunflower $(H$. annuus L.) and Jerusalem artichoke ( $H$. tuberoses L). Pl. Dis., 75: 230.

Joksimovic, J., A. Jovanka, R. Marinkovic, and Jovanovi, D. 2006. Genetic control of oleic and linoleic acid contents in sunflower. Helia, 29(44): 33-40.

Kolte, S.J. 1985. Diseases of Annual Edible Oilseed Crops III. CRC Press, Florida, pp. 996.

Mmbaga, T.M., and Sauvé, R.J. 2004. Management of powdery mildew in flowering dogwood in the field with biorational and conventional fungicides. Canadian J. Plant Sci., doi: 10.4141/P03-104.

Nene, Y. L. and Thapliyal, P. N., 1993, Fungicides in Plant Disease Control. Third Edition, Oxford and IBH Publishing Co. Pvt. Ltd., New Delhi, India, pp. 311-348.

Panse, V.G. and Sukhatme, P.V. 1985. Statistical Methods for Agricultural Workers. ICAR Publications, New Delhi, India, pp. 359.

Patel, M.K., Kamat, M.N. and Bhide, V.P. 1949. Fungi of Bombay. Indian Phytopath., 02: 142.

Prasada, R. Jain, J.P. and Bhatnagar, M.K. 1968. Sphaerotheca fuliginea (Schlecht) Pollaci on sunflower (Helianthus annuus L.), a new record for Rajasthan, India. Indian Phytopath., 21: 449-451.

Sindagi, S.S. and Virupakshappa, K. 1986. Sunflower. Indian Council of Agricultural Research Publication, New Delhi, pp. 37.

Singh, R.S. 1984. Introduction to Principles of Plant Pathology. Third edition, Oxford and IBH Publications, New Delhi, India, pp. 608.

Wheeler, B.E.J. 1969. An Introduction to Plant Disease. John Wiley Sons Ltd., London, p. 301.

\section{How to cite this article:}

Madhusudhan, P., Y. Narasimhudu, K. Ashok Kumar, S. Neelima and Sarma, A.S.R. 2017. Management of Sunflower Powdery Mildew Using Fungicide. Int.J.Curr.Microbiol.App.Sci. 6(7): 1261-1264. doi: https://doi.org/10.20546/ijcmas.2017.607.153 